sunshine is negligible or rendered ineffective by clothing.

It has thus been shown that perfectly calcified and regularly arranged teeth can be produced by including in the maternal diet during pregnancy and lactation, and in the diet of the offspring at the time of dental development, substances containing much vitamin $\mathrm{D}$, calcium and phosphorus, such as milk, eggs, fish and animal fats, and that cereals, especially those rich in embryo such as oatmeal, tend to produce hypoplastic teeth and call for a correspondingly larger supply of calcifying foods for good development. It has further been established that the teeth of the majority of children in Great Britain are imperfect in structure: that dental caries is more likely to attack such teeth than perfect teeth with normal enamel and dentine and a smooth surface ; that the resistance to caries can be increased independently of the original structure by giving a diet containing much vitamin $\mathrm{D}$, calcium and phosphorus or decreased by a diet rich in cereals. If these general principles of feeding were widely adopted, there is little doubt that dental caries (and also pyorrhœa, to which a deficient intake of vitamin A predisposes) "will cease to be the scourge they are at the present time". It may finally be pointed out that none of these conclusions conflicts with the generally accepted idea that the exciting cause of caries is the growth of micro-organisms in the mouth: the novelty is the proof that the tooth can resist the onslaught of the microbes by the absorption and assimilation into the body tissues of certain specific dietary factors.

\title{
Obituary
}

\section{Mr. E. M. Eden}

$\mathrm{E}$ DGAR MARK EDEN died on February 10 at the age of sixty years. He was the eldest son of William Eden, an artist, and was educated at University College, London. After a period with Messrs. Willans and Robinson, ended by ill-health from which he was never wholly free, he became a demonstrator at University College under Prof. Hudson Beare, by whom he was greatly influenced. In 1907 he became lecturer at Armstrong College, where he remained until his life-work began in 1915.

The National Physical Laboratory had undertaken the testing of all gauges for the manufacture of munitions. The old methods were inadequate to deal with the immense number of gauges, and especially screw gauges; entirely new and simpler methods were necessary. Here Eden's genius found its appropriate field. Many others shared in the work; but they would agree that every method finally adopted owed something to his inspiration, and that many of the most important owed everything. The simple machines that he devised for the most intricate measurements did much more than solve an urgent war problem. They enabled British manufacturers to test their own products and to raise appreciably their standard of accuracy. In the list of those who have led the post-War reconstruction of our industries Eden's name should stand high.

In 1919 Eden joined the original staff of the newly founded Research Laboratories of the General Electric Co., Ltd., as head of the workshops. His work now covered a much wider range, but knowledge of it was necessarily confined to a narrower circle. Discerning visitors to the Physical Society's Exhibition will have realised that its quality remained unchanged; but only his colleagues know how much of any success they may have achieved is due to it.

It is impossible to describe examples of his work in a few words; reference must be made to published accounts, for example, in Rolt's "Gauges and Fine Measurements" and in the Journal of Scientific Instruments (May 1922, and vol. 2, p. 119). All his work had a common feature, an economy of means and of material characteristic alike of the best science and the best art. Among modern Englishmen only Rayleigh and Horace Darwin can be compared with him in this matter. Like them he always went straight to fundamentals; he would not even take a hackneyed formula from a textbook; he always worked it out for himself. The colleague who brought him a sketch was often disconcerted to find the final apparatus shorn of all his cherished ingenuities; but it always worked at a first trial, and achieved exactly what was required of it, neither more nor less.

The same hatred of elaboration and ostentation inspired Eden's private life. He loved wild flowers, but not the formal garden ; the elegance of Mozart, but not the grandeur of heavy orchestration. It made him a true peace-lover; only his duty to his young family persuaded him, after a bitter struggle, to take even an indirect part in hated strife. Yet he was no shrill pacifist; quarrels vanished like smoke before his genial smile and kindly, but caustic, humour. He was a perfect host; and his accounts of workshop doings at staff meetings were so entertaining that they became recognised as among the Laboratory treats. We are all much poorer for his loss, though the world at large may never know it. He leaves a widow and four sons.

\section{Dr. H. M. CADell}

The sudden death of Dr. H. M. Cadell on April 10 at the age of seventy-three years has deprived Edinburgh and its neighbourhood of a distinguished scientific worker and of one who played a conspicuous and most useful part in the life of the community. Born in 1860, he was educated at the University of Edinburgh and at 
Clausthal Royal Mining Academy, Germany. He was one of the first band of students who studied under Archibald Geikie, and at the age of twentythree years he became a member of H.M. Geological Survey. He always regarded it as a privilege that he was sent to the field as a junior member of the staff under Peach and Horne in the survey of the north-west Highlands, and an account of his laboratory experiments illustrating the mode of production of the complicated tectonics of that region is included in their classic memoir. On succeeding to the family estate in 1888 he retired from the Survey after only five years' service, but his interest in geology and geography continued unabated, and he was the author of a long series of geological and geographical papers, many of which were the results of observations made during his frequent and extensive travels.

Cadell's more important publications dealt with the oil-shale field and general geology of West Lothian, and with the geological history of the Forth valley. $\mathrm{He}$ was essentially a practical geologist and took an active part in the development of the coal- and oil-shale fields of West Lothian, and in the reclamation of the muddy foreshore along parts of the Firth of Forth. He was also interested in the exploitation of the coal resources of Spitsbergen.

The various scientific societies in Edinburgh, particularly the Royal Scottish Geographical Society, the Royal Society of Edinburgh, and the Edinburgh Geological Society owe Dr. Cadell a great debt of gratitude for many services rendered and for generous financial support. $\mathrm{He}$ led the life of a country gentleman and became a county magnate, serving in various capacities on the County Council of Linlithgow, and becoming Deputy-Lieutenant. He also served in the 'volunteers' for twenty-four years and retired in 1906 with the rank of Lieut.-Colonel and Hon. Colonel, V.D.

Cadell's services to the University of Edinburgh were many, and special mention may be made of the interest he took in the founding of the chairs of mining and of geography. As a recognition of his scientific attainments and public work he was awarded the honorary degree of LL.D. by the University in 1932.

It is rare to find combined in one personality gifts of such a varied nature, and he will be greatly missed in Edinburgh.

T. J. JEHU.

\section{DR. J. P. VAN DER STOK}

Johannes Paulus van Der StoK was born on January 14, 1851, at Zuilen, near Utrecht. He studied at the University at Utrecht and took his degree of doctor in physics and mathematics in 1874. In 1877 he went to Java as sub-director of the Magnetic and Meteorological Observatory at Batavia, was appointed director in 1882 and retired as such in $\mathbf{1 8 9 9 .}$

Van der Stok's first publications dealt with periods in terrestrial magnetism and meteorology in relation to the sun and moon, and the observatory at Batavia co-operated in many international researches in seismology, terrestrial magnetism and cloud studies. His most important work, however, were his tidal studies, based on Darwin's method. By a skilful arrangement of direct readings of tide gauges at well-chosen hours, and many original methods of discussing the results, he was able to disentangle completely the very complex tidal phenomena in the Archipelago. The results have been published in a series of sixteen papers and in the atlas "Wind, Weather, Tides and Tidal Streams in the East Indian Archipelago". Tide prediction, highly important for shipping especially near Sourabaya, has since been carried out by Van der Stok's methods largely by native assistants.

After his return to Holland, Van der Stok became director of the oceanographical department of the Meteorological Institute at De Bilt and remained so until 1923. There his principal work was the supervision of the publication of oceanographical atlases of the Indian and Atlantic Oceans, but he continued also his tidal work and published an "Elementary Theory of the Tides" with numerous tidal constants for the East Indian Archipelago, which has been translated into German. He also published through the Amsterdam Academy of Sciences many studies in climatology and dynamical meteorology. $\mathrm{He}$ was the first to introduce 'stability' as a numerical indication of the degree of variability in direction of wind- and current-vectors, and one of the first to use and investigate frequency tables and curves in climatology-we need only mention his treatment of tides in the North Sea and of the climate of the North Sea deduced from lightship observations. After several years of illness, borne with exceptional patience and cheerfulness, he died on March 29, 1934, at the age of eighty-three years. Throughout the world his name will be gratefully remembered.

E. van Everdingen.

THE death is announced of Frederick William Christian, anthropologist and explorer, city librarian of Christchurch, New Zealand, which took place at the age of sixty-six years at Wellington, N.Z. F. W. Christian, the son of E. H. Christian, was born at Putney Hill on June 15, 1867, and educated at Eton and Balliol College, Oxford. After taking his degree he became interested in the exploration of the Pacific, and more particularly of the islands of Micronesia. His ethnographical observations in this area were of enduring value and continue to be the best and most authoritative account of some of the lesser-known islands. His best-known and most frequently quoted work is "The Caroline Islands" (1899). He also published "Eastern Pacific Lands" (1910) and a comparative study of a number of the Oceanic languages. $\mathrm{He}$ was a frequent contributor to the publications of the Polynesian Society and other scientific journals. 